\title{
KARAKTERISASI FISIOKIMIA DAN FUNGSIONAL KITOSAN YANG DIPEROLEH DARI LIMBAH CANGKANG UDANG WINDU
}

\author{
Irwan Sofia*, Pirman, dan Zulfiana Haris \\ Program Studi Teknik Kimia, Politeknik Negeri Ujung Pandang \\ Jalan Perintis Kemerdekaan Km. 10 Tamalanrea, Makassar 90242 \\ Email: pnup@poliupg.ac.id
}

\begin{abstract}
Abstrak
Tujuan penelitian adalah mengamati pengaruh modifikasi perlakuan proses terhadap sifatsifat fisiokimia dan fungsional kitosan asal udang Windu (Penaeus monodon). Kitosan asal cangkang kepiting (crabshell) produk Sigma Co. USA digunakan sebagai pembanding. Analisis karakteristik fisiokimia meliputi perolehan hasil, kadar air, nitrogen, abu, derajat deasetilasi (DD), viskositas, kelarutan dalam asam, dan densitas curah. Analisis sifat fungsional meliputi kemampuan mengikat air (water binding capacity, WBC), dan kemampuan mengikat lemak (fat binding capacity, FBC). Perolehan maksimum diperoleh dengan mode operasi DMPAK 19,3\% basis kering. Perolehan rata-rata dari mode proses (DKMPA, DMPAK, dan DPMKA) 17,56\%. Perolehan paling rendah diperoleh untuk DAMPK. Rata-rata kadar abu kitosan dari tiga proses pertama lebih rendah dari 1\%, sedangkan pada proses DAMPK kadar abu 1,6\%. Kitosan udang windu mempunyai viskositas sedang $(>250$ cP) yaitu antara 330,3-461,3 cP, sesuai dengan kitosan technical grade produk Sigma, Co. Densitas curah berkisar antara 0,166-0,178 g/mL, lebih rendah dari densitas curah kitosan komersial asal kepiting antara 0,18-0,33 g/mL. Kemampuan mengikat air sekitar 504-529\% adalah lebih rendah dari WBC crab kitosan yang berkisar pada 581-1.150\%, dan kemampuan mengikat lemak (FBC) rata-rata 416,5\% untuk minyak kedelai, 503\% untuk minyak jagung, dan $400,8 \%$ untuk minyak wijen adalah relatif lebih tinggi dari FBC kitosan komersial yang berkisar antara 399,9-413,4\%.
\end{abstract}

Kata Kunci : kitosan, udang windu, kemampuan mengikat lemak, derajat deasetilasi (DD)

\begin{abstract}
The research was aimed at ascertaining the influences of process modification on the physiochemical and functional characteristic of udang Windu (Penaeus monodon) shell. The products of Sigma Co. were taken as comparing variable. All the physiochemical of the samples, namely yield, water, nitrogen, ash content, degree of deacetylation (DD), viscosity, acid solubility, and bulk density were analyzed. The functional characteristic analysis included water binding capacity (WBC), and fat binding capacity (FBC). The optimum yield was obtained by DMPAC process $19.3 \%$ (dry basis). The average yield gained from the DCMPA, DMPAC, and DPMCA was $17.56 \%$. The smaller yield was made from the DAMPC process. The average ash content obtained from the three processes was smaller than $1 \%$, but that of the DAMPC was 1.6\%. The chitosan obtained from Windu shrimp had an average viscosity ( $>200 \mathrm{cP}$ ), namely between $330.3-461.3 \mathrm{cP}$, accorded to chitosan type of technical grade (the product of Sigma). The density bulk of chitosan ranged between 0.166-0.178 $\mathrm{g} / \mathrm{mL}$, smaller than that chitosan crab of Sigma Co., between $0.18-0,33 \mathrm{~g} / \mathrm{mL}$. The WBC was about 504-529\%, lower than crab chitosan 581-1150\%. Meanwhile, on average its FBC was $416 \%$ for soybean oil, $503 \%$ for corn oil, and $400.8 \%$ for sesame oil, which was relatively higher than the FBC of commercial chitosan (the product of Sigma Co.), which was between 399.9-413.4\%.
\end{abstract}

Keywords : chitosan, penaeus monodon, fat binding capacity, degree of deacetylation (DD)

*korespondensi 


\section{Pendahuluan}

Indonesia merupakan salah satu negara produsen udang Windu (Penaeus Monodon) terbesar di dunia. Data dari Direktorat Jendral Budidaya Departemen Kelautan dan Perikanan menunjukkan bahwa areal tambak udang nasional pada tahun 2006 mencapai 480.850 ha, dengan kapasitas produksi 281.901 ton. Sebagian besar produksi udang tersebut menjadi komoditas ekspor yang sebelumnya dikemas dalam bentuk udang beku olahan (headless atau peeled). Pada proses pembekuan (cold storage) untuk ekspor tersebut, sekitar $60-70 \%$ bagian dari berat udang jadi limbah, terutama bagian kulit dan kepala (Prasetio, 2006).

Limbah kulit udang mengandung konstituen utama terdiri dari protein, kalsium karbonat, kitin, pigmen, mineral dan lain-lain. Kitin dari limbah cangkang udang dapat diubah menjadi kitosan melalui beberapa tahapan proses. Dari sisi ekonomi, pembuatan kitin menjadi kitosan dan turunannya seperti karboksil metil kitosan (KMK) sangat prospektif karena kitosan dan derivatnya tersebut sangat luas aplikasinya, di samping bahan baku berupa limbah dan berasal dari sumber daya lokal.

Kitosan hasil deasetilasi dari kitin yang telah luas digunakan di berbagai industri seperti industry makanan, pengolahan air, pertanian dan bioteknologi, serta untuk aplikasi medis dan kosmetika. Selama ini produk-produk turunan kitosan seperti KMK dan kitosanoligomer, dibuat dari kitosan asal hewan laut seperti kepiting dan udang karang (crawfish, lobster). Karakteristik dari produk kitosan sangat tergantung jenis sumber hewan laut dan metode produksinya.

\section{Deproteinasi}

Deproteinasi (DP) dilakukan melalui ektraksi dengan larutan $\mathrm{NaOH}(1-10 \%)$ pada temperatur $\left(65-100{ }^{\circ} \mathrm{C}\right)$, selama 1 hingga 6 jam (No dan Meyers, 1995). Shahidi dan Synowiecki (1991) melaporkan bahwa ekstraksi dengan perbandingan larutan alkali dengan solid 1:10 selama 2 jam dengan pengaduk, dapat menarik seluruh protein dalam cangkang kepiting. No dkk. (2000a) telah mendapatkan hasil/perolehan (yield) yang optimum dengan proses DP pada $121^{\circ} \mathrm{C} / 15$ psi menggunakan larutan $\mathrm{NaOH} 3$ $\%$ dan rasio padatan:pelarut adalah 1:10. No dkk. (2000b) juga telah mempelajari karakteristik kitosan yang diproses tanpa deproteinasi. Kitosan yang dibuat tanpa DP mempunyai derajat deasetilasi, kelarutan, kadar air, kapasitas mengikat lemak dan kemampuan menyerap warna yang rendah dibandingkan dengan kitosan yang dibuat dengan DP, tetapi kitosan tanpa DP mempunyai berat molekul dan viskositas lebih tinggi.

\section{Demineralisasi}

Demineralisasi (DM) dilakukan melalui ekstraksi dengan larutan asam klorida pada suhu ruang. Waktu proses demineralisasi yang lebih dari 24 jam dapat mengurangi kandungan abu cukup besar tetapi juga menyebabkan degradasi polimer. Penting diperhatikan jumlah asam yang ditambahkan harus sesuai secara stoikiometri atau lebih besar dari jumlah mineral yang ada dalam cangkang untuk menyakinkan reaksi dekalsifikasi berjalan sempurna (Shahidi dan Synowiecki, 1991).

\section{Dekolorisasi}

Dekolorisasi (DK) dari kitin bertujuan menarik zat warna dengan pelarut. Pelarut yang dapat digunakan adalah: campuran etanol-ether, natrium hipoklorida, kloroform, $\mathrm{H}_{2} \mathrm{O}^{2}$, etil asetat, dan aseton. No dan Meyers pada tahun 1995 telah melakukan dekolorisasi kitin dari udang lobster dengan aseton, yang diikuti proses bleaching menggunakan larutan $\mathrm{NaOCl}$ 0,315\%. Moorjani (1975) menyatakan bahwa proses dekolorisasi dapat mengurangi viskositas dari produk kitosan.

\section{Deasetilasi}

Deasetilasi (DA) kitin dilakukan dengan melarutkan dalam larutan $\mathrm{NaOH}$. Beberapa proses DA dilakukan dengan $\mathrm{NaOH}$ yang dilarutkan dalam air dengan menambahkan pelarut organik seperti 2-propanol, 2-metil 2propanol atau aseton. Biasanya untuk mendapatkan derajat deasetilasi yang tinggi diperlukan dua atau tiga kali pengolahan dengan alkali. Akan tetapi dengan perlakuan ini akan menyebabkan degradasi rantai molekul, sehingga akan diperoleh kitosan dengan berat molekul lebih rendah. Proses deasetilasi kitin yang mudah dan murah telah disarankan oleh Alimuniar dan Zainuddin (1992), menggunakan $\mathrm{NaOH}$ pekat pada suhu ruang $30^{\circ} \mathrm{C}$ tanpa pemanasan. Dengan $\mathrm{NaOH}$ $50 \%$, diperoleh kitosan dengan derajat asetilasi 87\%. No dkk. (2000a) telah melakukan proses DA kitin dalam autoclave pada kondisi 15 psi dan $121{ }^{\circ} \mathrm{C}$ dengan 
konsentrasi dan waktu reaksi $\mathrm{NaOH}$ yang berbeda-beda. Peneliti menyatakan DA efektif pada kondisi tersebut dilakukan dengan $\mathrm{NaOH}$ $45 \%$ selama 30 menit, dengan ratio padatan dan solid 1:15. Proses ini akan diperoleh derajat deasetilasi dan berat molekul kitosan yang tinggi, dan viskositas yang sesuai dengan kitosan komersial.

Pada penelitian ini telah dilakukan empat modifikasi mode perlakuan proses, dengan memvariasikan mode-mode proses di atas. Pembuatan kitosan dilakukan di Laboratorium Teknologi Proses, Jurusan Teknik Kimia Politeknik Negeri Ujung Pandang. Bahan baku limbah cangkang udang Windu diperoleh dari perusahaan pengolahan udang beku ekspor PT Sittomas Mina Lestari yang berlokasi di Kawasan Industri Makassar.

Tujuan dari penelitian adalah:

a. mengamati karakteristik fisio kimia dan sifat-sifat fungsional kitosan dari limbah cangkang udang, yang diperoleh dengan beberapa modifikasi proses, dan dibandingkan dengan karakteristik kitosan komersial.

b. memgamati pengaruh perubahan posisi perlakuan demineralisasi (DM) dan deproteinisasi (DP) selama produksi kitosan

c. mengamati pengaruh perubahan penempatan proses deasetilasi (DA) pada perlakuan pembuatan kitosan.

\section{Kajian Pustaka}

Kitosan adalah senyawa biopolimer yang diturunkan dari kitin, yaitu senyawa dengan struktur homopolimer P-(1-4) Nacetyl-D-glucosamine. Kitin terdapat secara luas pada hewan-hewan invetebrata di laut, serangga, jamur dan juga ragi. Umumnya cangkang dari hewan laut mengandung 30$40 \%$ protein, $30-50 \%$ kalsium karbonat dan kalsium fosfat, dan 20-30\% kitin. Kitin terdapat pada hampir semua hewan laut berkulit keras seperti udang, kepiting dan lobster.

Kitin dan kitosan mempunyai struktur kimia yang sama. Kitin terdiri dari rantai lurus asetil-glukosamin, sedangkan kitosan diperoleh melalui pemutusan gugus asetil $\left(\mathrm{CH}_{3}-\mathrm{CO}\right)$. Proses pemutusan ini disebut dengan deasetilasi. Perbedaan utama antara kitin dengan kitosan adalah kadungan asetil dari polimernya. Kitosan adalah turunan kitin yang paling banyak kegunaannya.

Kitosan yang diperoleh dari hasil deasetilasi kitin berbentuk serbuk putih yang tidak larut dalam air, tetapi dapat larut dan tidak terdegradasi dalam larutan asam asetat dan asam formiat yang encer dengan membentuk larutan viskos pada $\mathrm{pH}$ dibawah 6,5 . Kitosan mempunyai bobot molekul yang relatif tinggi sekitar $1,2 \times 10^{5} \mathrm{Da}$, tergantung pada degradasi selama proses deasetilasi, dan mempunyai titik lebur $134,5{ }^{\circ} \mathrm{C}$. Kitosan tidak beracun dan mudah terbiodegradasi.

Kitosan adalah produk deasetilasi dari kitin yang mudah larut dalam air, dan asam seperti asam asetat dan asam formiat. Kitosan sangat mudah berinteraksi dengan zat-zat organik seperti protein dan lemak. Karena itu, kitosan lebih banyak digunakan pada berbagai industri terapan, kesehatan dan industri pangan. Sifat fungsional kitosan yang tidak beracun dan mudah membentuk emulsi juga telah dimanfaatkan pada industri pangan sebagai senyawa pembentuk formula seperti pengikat air dan lemak, pembentuk gel, pengental, dan agen penstabil (Shahidi dkk., 1999).

Derajat Deasetilasi dari kitosan bervariasi antara 56-99\%, rata-rata $80 \%$ tergantung dari sumber dan metoda pembuatan (No dkk., 2000a). Derajat deasetilasi adalah karakter penting dari produk kitosan, yang sangat berpengaruh terhadap sifat-sifat kimia dan kegunaannya. Derajat deasetilasi juga berpengaruh terhadap kemampuan biodegrabilitas dan imunologik (Tolaimate dkk., 2000). Beberapa metode pengujian derajat asetilasi kitosan telah dilakukan antara lain metode titrasi potensiometri, ninhydrin test, NMRspectroscopy, titrasi hidrogen bromida, infrared spectroscopy, UV-spektrofotometri.

\section{Metodologi}

Penelitian dilakukan di Laboratorium Teknologi Proses, Jurusan Teknik Kimia Politeknik Negeri Ujung Pandang. Bahan baku limbah cangkang udang Windu diperoleh dari perusahaan pengolahan udang beku untuk ekspor, PT. sittomas Mina Lestari yang berlokasi di Kawasan Industri Makassar (PT. KIMA).

\section{Persiapan bahan dan alat}

Persiapan bahan baku limbah cangkang udang diawali dengan membersihkan cangkang udang basah dari kotoran-kotoran organik yang menempel dengan air hangat yang mengalir, selanjutnya di jemur hingga cukup kering dengan sinar matahari selama 2 3 hari. Cangkang udang kering kemudian 
dihaluskan dalam alat Crusher dan dilanjutkan dengan pengayakan hingga diperoleh bahan baku cangkang udang halus 200 mesh. Pelarut untuk ektraksi yaitu larutan $\mathrm{NaOH} 3,5 \%$ dan $50 \%$ (b/v), HCl 1 N, NaOCl 0,32\% (b/v) disiapkan untuk keperluan proses ekstraksi, deproteinasi, demineralisasi, dekolorosasi, dan deasetilasi.

\section{Prosedur Kerja Pembuatan Kitosan}

Deproteinasi cangkang udang (kepala dan ekor) yang telah halus atau cangkang udang yang telah didemineralisasi, akan dilakukan penghilangan protein dengan larutan $\mathrm{NaOH} 3,5 \%$ (b/b) selama 2 jam pada suhu 65 oC dan dilakukan pengadukan. Ratio padatan dan pelarut yang digunakan adalah 1:10 (b/v) (No dkk., 2000). Kemudian sampel disaring dan dicuci dengan aquadest dan dikeringkan di oven.

Demineralisasi cangkang udang halus atau cangkang udang yang telah dideproteinisasi, dilakukan dengan larutan $\mathrm{HCl} 1 \mathrm{~N}$ selama 30 menit pada suhu kamar, dengan ratio padatan dan larutan 1:15 (b/v) (No dkk., 2000b). Selanjutnya disaring, dicuci dengan aquadest sampai netral dan dikeringkan di oven.

Dekolorisasi sampel dengan menambahkan aseton selama 10 menit dan dikeringkan selama 2 jam pada suhu ruang, dilanjutkan dengan pemucatan dengan menambahkan natriumhipoklorida $(\mathrm{NaOCl})$ $0,32 \%$ selama 5 menit pada suhu ruang. Rasio padatan dan pelarut adalah $1: 10(\mathrm{~b} / \mathrm{v})$ atas dasar berat kering padatan/cangkang (No, dkk., 2003). Sampel selanjutnya dicuci dengan aqudes dan dikeringkan secara vakum selama 2-3 jam hingga terbentuk bubuk halus/tepung.

Proses Proses deasetilasi dilakukan dalam autoclave pada tekanan $15 \mathrm{psi}$, suhu $121^{\circ} \mathrm{C}$ selama 30 menit. Deasetilasi dilakukan dengan menambahkan larutan $\mathrm{NaOH} 50 \%$, dengan perbandingan padatan dan larutan 1:10 (b/v) menurut metode No dkk. (2003). Sampel kitosan dicuci untuk dinetralkan dengan air bersih mengalir. Kemudian air diuapkan dan dikeringkan pada suhu $60^{\circ} \mathrm{C}$ selama 24 jam di oven.

Dilakukan empat variasi modifikasi perlakuan proses dengan urutan proses masing-masing adalah: DKMPA (dekolorisasi, demineralisasi, deproteiniasi ,deasetilasi); DMPAK (demineralisasi, deproteinasi, deasetilasi, dekolorisasi); DAMPK (deasetilasi, demineralisasi, deproteinasi, dekolorisasi), DPMKA (deproteinasi, demineralisasi, dekolorisasi, deasetilasi).

Kitosan asal cangkang kepiting ( $\mathrm{crab}$ shell), produk Sigma Chemical Co. USA digunakan sebagai pembanding untuk sifatsifat fisiokimia dan fungsional kitosan yang dihasilkan dari beberapa modifikasi pembuatan diatas.

\section{Hasil dan Pembahasan}

Hasil dari analisis terhadap sifat-sifat fisika dan kimia dari produk kitosan yang diperoleh ditampilkan pada Tabel 1 sampai 6 berikut ini.

\section{Perolehan}

Perolehan dihitung berdasarkan berat kering kitosan yang diperoleh dari 200-300 gram cangkang udang kering halus. Perolehan kitosan dari masing-masing modifikasi bervariasi dari 0,79-19,3 \%. Perolehan tertinggi diperoleh dari urutan pembuatan DMPAK, dikuti berturut-turut oleh DKMPA, DPMKA(kontrol), dan paling rendah DAMPK.

Hasil perhitungan pada Tabel 1 menunjukkan bahwa dengan proses DKMPA diperoleh hasil yaitu $16,8 \%$ sedikit berbeda dari metode umum DPMAK $(16,6 \%)$. Perolehan kitosan sekitar 14\% diperoleh dari sumber krill dan hasil 18,6\% dari bahan limbah cangkang udang laut telah dilaporkan oleh Alimuniar dan Zainuddin (1992). Perolehan antara 16,6-19,3\%, adalah lebih rendah dari yang diperoleh dari cangkang udang karang (lobster) $\pm 23 \%$ yang telah dilaporkan oleh No dkk. (1989).

Tabel 1. Perolehan produksi kitosan dari cangkang udang windu (basis kering)

\begin{tabular}{cc}
\hline Jenis Sampel & Perolehan $(\%)$ \\
\hline DKMPA & 16,8 \\
DMPAK & 19,3 \\
DAMPK & 0,79 \\
DPMKA & 16,6 \\
\hline
\end{tabular}

Hasil di atas juga menunjukkan bahwa urutan proses DAMPK memberikan perolehan yang sangat sedikit, sehingga hanya tiga metode di atas (DKMPA, DMPAK, dan DPMKA) yang disarankan untuk pembuatan kitosan. Penempatan proses deasetilasi pada tahap awal proses secara drastis mengurangi perolehan produk kitosan. 


\section{Kadar Air}

Hasil dari analisis kadar air, kadar abu, dan kandungan nitrogen dari sampel kitosan ditunjukkan pada Tabel 2.

Tabel 2. Hasil Analisis Kadar Air, Kadar Abu, Kadar Nitrogen dari Kitosan

\begin{tabular}{cccc}
\hline Sampel & $\begin{array}{c}\text { Kadar } \\
\text { Air (\%) }\end{array}$ & $\begin{array}{c}\text { Kadar Abu } \\
(\%)\end{array}$ & $\begin{array}{c}\text { Kadar } \\
\text { Nitrogen } \\
(\%)\end{array}$ \\
\hline DKMPA & 0,35 & 0,51 & 8,22 \\
DMPAK & 0,60 & 0,46 & 8,02 \\
DAMPK & 0,66 & 1,60 & 6,81 \\
DPMKA & 0,70 & 0,37 & 8,09 \\
Kitosan & $\left.3,50^{*}\right)$ & $\left.1,80^{*}\right)$ & $8,50^{*}$ \\
(Sigma Co) & & & \\
\hline
\end{tabular}

*) Sampel Kitosan komersial

Sampel kitosan yang dihasilkan dari limbah cangkang udang windu mempunyai kandungan air bervariasi antara 0,35\% hingga $0,70 \%$. Hasil analisis kitosan komersial produk Sigma diperoleh kandungan airnya sekitar 3,5\%. Nilai ini relatif tinggi dibandingkan dengan kitosan dari cangkang udang. Menurut literatur chitosan adalah senyawa yang higroskopis, sehingga sangat mungkin nilai diatas adalah harga relatif pada saat dilakukan analisis, kadar air yang tinggi dari kitosan tersebut disebabkan karena penyerapan uap air selama penyimpanan. Dengan penyimpan yang lama kemungkinan terjadi perubahan kadar air, tergantung kondisi kelambaban lingkunganya.

\section{Kadar Abu}

Proses deminerasilasi (DM) adalah tahapan perlakuan untuk menghilangkan kalsium karbonat. Tanpa proses demineralisasi ini kandungan abu bahan akan sangat tinggi. Kadar abu bahan adalah parameter penting fungsional kitosan. Tingginya kadar abu dapat berpengaruh terhadap kelarutan, yang dapat berkontribusi terhadap rendahnya viskositas, atau juga dapat berpengaruh terhadap karakteristik fisiokimia lainnya. Syarat mutu kitosan kualitas tinggi harus mempunyai kadar abu lebih rendah dari 1\% (No dan Meyers, 1995).

\section{Kadar Nitrogen}

Kadar nitrogen dari sampel kitosan asal cangkang udang windu bervariasi antara $8,02 \%$ hingga $8,22 \%$ atas dasar basis kering, kecuali mode proses DAMPK (6,81\%). Berturut-turut kandungan nitrogen sampel kitosan untuk DKMPA, DMPAK, dan DPMAK (kontrol) adalah 8,22\%, 8,02\%, dan 8,09\%. Nilai kandungan nitrogen dari kitosan cangkang udang windu ini sedikit lebih besar dibandingkan yang dilaporkan oleh No dan Meyers (1995) yang berkisar antara 7,06\% hingga 7,97\% masing-masing untuk kitosan dari kepiting laut (crab shell) dan udang laut (shrimp shell). Jika dibandingkan dengan kandungan nitrogen kitosan komersial dari kepiting produk Sigma, kandungan nitrogen dari kitosan dari kedua sumber tersebut tidak terlalu mempunyai perbedaan yang signifikan.

\section{Derajat Deasetilasi}

Derajat deasetilasi (DD) dari sampel kitosan udang windu yang diperoleh bervariasi antara $66,34 \%$ hingga $82,07 \%$ dengan rata-rata peroleh $74,13 \%$ (Tabel 3). Menurut No dan Meyers (1995), DD dari kitosan berkisar 56-99\% dengan rata-rata 80\%. Sampel dengan mode pembuatan DMPAK mempunyai DD paling tinggi, yaitu 82,07\% diikuti dengan DPMKA, DKMPA, dan DAMPK.

Pada Tabel 3, terlihat bahwa nilai \%DD dari komersial kitosan lebih tinggi dari hasil yang diperoleh dari ke empat variasi modifikasi metode pembuatan yang dilakukan. Nilai dari \%DD tidak hanya sangat tergantung dari sumber kitosan dan metode pemurniannya (No dkk., 1989), tetapi juga pada metode analisis yang digunakan, cara penyiapan sampel, dan tipe instrument yang digunakan, dan faktor-faktor lainnya juga mungkin mempengaruhi analisis dari \%DD (Khan dkk., 2002). Nilai \%DD yang relatif rendah pada mode proses DAMPK kemungkinan metode yang tidak sesuai atau adanya pengotor.

Tabel 3. Derajat deasetilasi (DA) dari kitosan sampel dan kitosan komersial

\begin{tabular}{cc}
\hline Jenis Sampel & DD (\%) \\
\hline DKMPA & 71,63 \\
DMPAK & 82,07 \\
DAMPK & 66,34 \\
DPMKA & 76,48 \\
Kitosan (Crabshell) & $>85,0^{*}$ \\
\hline *)Data menurut speksifikasi produk Sigma, Co USA.
\end{tabular}

*)Data menurut speksifikasi produk Sigma, Co USA.

\section{Viskositas}

Viskositas kitosan banyak dilaporkan dalam beberapa literatur umumnya berkisar antara 60 hingga $780 \mathrm{cP}$ (Alimuniar dan Zainuddin, 1992). Tabel 4 menunjukkan hasil analisis viskositas, kelarutan, densitas curah kitosan dari udang windu. 
Tabel 4. Hasil Analisis Viskositas, Kelarutan dan Densitas Curah Kitosan

\begin{tabular}{cccc}
\hline Sampel & $\begin{array}{c}\text { Viskositas\#) } \\
\text { (cP) }\end{array}$ & $\begin{array}{c}\text { Kelarutan } \\
(\%)\end{array}$ & $\begin{array}{c}\text { Densitas } \\
\text { curah } \\
(\%)\end{array}$ \\
\hline DKMPA & 461,3 & 91,0 & 0,166 \\
DMPAK & 424,9 & 92,4 & 0,172 \\
DAMPK & 130,8 & 89,3 & 0,175 \\
DPMKA & 330,3 & 91,1 & 0,178 \\
Kitosan & $>250$ & 96,8 & 0,142 \\
(Crabshell) & & & \\
\hline
\end{tabular}

*) Kitosan yang dilarutkan dalam asam asetat $1 \%$.

Ada banyak faktor yang berpengaruh terhadap viskositas produk selama produksi seperti proses deasetilasi, konsentrasi pelarut, $\mathrm{pH}$ dan temperatur operasi. Morjani dkk. (1975) melaporkan viskositas larutan kitosan dalam asam asetat cenderung bertambah dengan penurunan $\mathrm{pH}$ larutan, tetapi akan berkurang dengan pengurangan $\mathrm{pH}$ dalam $\mathrm{HCl}$. Hasil analisis terlihat bahwa proses diawali dengan deminalisasi, dan dekolorisasi mempunyai viskositas lebih tinggi dibandingkan dengan proses yang diawali dengan deasetilasi dan deproteinasi (DP).

\section{Kelarutan}

Data kelarutan menunjukkan bahwa kelarutan kitosan dalam larutan asam asetat $1 \%$, pada pengadukan selama $240 \mathrm{rpm}$, dan perendaman dalam water bath air mendidih selama 10 menit. Hasil pengamatan menunjukkan kelarutan kitosan yang cukup baik yaitu rata-rata di atas $90 \%$. Dari literatur diperoleh bahwa rendahnya kelarutan disebabkan tidak sempurnanya proses penghilangan protein (deproteinasi), karena adanya sisa-sisa protein dalam sampel dapat mempengaruhi kelarutan.

\section{Densitas curah}

Penelitian dari No dan Meyers (1995) menyatakan bahwa densitas curah dari beberapa crab kitosan komersial berkisar antara 0,18 hingga $0,33 \mathrm{~g} / \mathrm{mL}$, menunjukan lebih dari 1,8 kali perbedaan porositas antara beberapa kitosan tersebut. Hasil analisis densitas produk kitosan dari udang windu hasil penelitian berkisar antara 0,166-0,178 $\mathrm{g} / \mathrm{mL}$. Hal ini menunjukkan bahwa kitin dari cangkang udang mempunyai porositas yang relatif lebih besar dari kitin kepiting. Densitas curah kitosan komersial Produk Sigma USA lebih rendah dibandingkan kitosan yang diperoleh dari udang windu. Densitas curah dari kitosan komersial yang rendah karena metode perlakukan awalnya (penghalusan) lebih sempurna dibandingkan dengan metode yang dikerjakan di laboratorium Cho dan No (1999) menyatakan bahwa rendahnya densitas curah menunjukkan bahwa kitosan dihasilkan mempunyai tingkat porositas yang tinggi. Hal ini kemungkinan disebabkan oleh konsentrasi alkali yang rendah pada proses deproteinasi.

\section{Kemampuan Mengikat Air}

Hasil analisis kemampuan mengikat air dari produk kitosan dari cangkang udang windu hasil percobaan ditunjukkan pada Tabel 5. Kemampuan mengikat air sampel berkisar 504-529\%. Hasil ini lebih rendah jika dibandingkan dengan WBC untuk kitosan yang telah dilaporkan oleh Rout (2001). Peneliti tersebut melaporkan WBC dari kitosan yang dihasilkan berkisar antara 581\% hingga $1150 \%$, dengan rata-rata $702 \%$.

Tabel 5. Hasil Analisis Kemampuan Mengikat Air

\begin{tabular}{lc}
\hline Jenis Sampel & WBC (\%) \\
\hline DKMPA & 529 \\
DMPAK & 504 \\
DAMPK & 519 \\
DPMKA & 511 \\
Kitosan (Crabshell) & 549 \\
\hline
\end{tabular}

Cho dan No (1999) juga telah melaporkan bahwa rentang WBC antara 458$805 \%$ dari lima kitosan komersial yang dianalisis berasal dari cangkang udang dan kepiting. Modifikasi perlakuan proses antara demineralisasi dengan deproteinasi dan deasetilasi memberikan efek terhadap peningkatan WBC. Deproteinasi dan deasetilasi sebelum dilakukan demineralisasi dapat meningkatkan WBC, demikian juga dengan proses perlakuan dekolorisasi.

\section{Kemampuan Mengikat Lemak}

Kemampuan mengikat lemak (FBC) dari sampel kitosan ditentukan dengan mencoba pengikatan dari tiga jenis minyak yaitu minyak kedelai, minyak jagung dan minyak wijen. Dari ketiga jenis minyak yang dianalisis, terlihat bahwa kemampuan minyak jagung relatif lebih baik dari kitosan yang dihasilkan dibandingkan dengan jenis minyak lainnya. Hasil analisis ditunjukkan pada Tabel 6.

Hasil analisis pengujian FBC terhadap ketiga jenis lemak di atas, menunjukkan bahwa penyerapan kitosan terhadap minyak jagung relatif tinggi, sedangkan terhadap 
minyak wijen lebih rendah. Studi sebelumnya yang dilakukan oleh Rout (2001) menunjukkan bahwa rata-rata FBC kitosan dari asal kepiting laut dan udang karang (lobster) berkemampuan menyerap lemak minyak kedelai berturut-turut adalah 587\% dan $706 \%$.

Tabel 6. Hasil analisis kemampuan mengikat lemak

\begin{tabular}{llll}
\hline Jenis Sampel & \multicolumn{3}{c}{ FBC (\%) } \\
\cline { 2 - 4 } & Kedelai & Jagung & Wijen \\
\hline DKMPA & 409 & 551 & 407 \\
DMPAK & 425 & 499 & 401 \\
DAMPK & 410 & 427 & 383 \\
DPMKA & 422 & 535 & 412 \\
Kitosan & 393,9 & 413,4 & 399,6 \\
(Crabshell) & & & \\
\hline
\end{tabular}

Analisis FBC yang diperoleh rata-rata untuk minyak kedelai adalah 416,5\%, untuk minyak jagung 503\%, dan 400,8\% untuk minyak wijen. Ini sesuai dengan FBC beberapa sampel kitosan antara 314\% hingga 535\%, dengan rata-rata $417 \%$ seperti yang dilaporkan oleh No et al. (1998).

\section{Kesimpulan}

Perolehan kitosan maksimum diperoleh dengan mode operasi DMPAK sebesar 19,3\% (basis kering). Rata-rata perolehan dari tiga mode proses (DKMPA, DMPAK, dan DPMKA) 17,56\%, kecuali mode proses DAMPK hanya $0,79 \%$ Penempatan proses deasetilasi (DA) pada tahap awal tidak disarankan, karena kitosan yang diperoleh mempunyai perolehan dan derajat deasetilasi yang rendah. Kadar abu kitosan dari tiga proses (DKMPA, DMPAK, dan DPMKA) ratarata dari lebih rendah dari $1 \%$, kecuali pada proses DAMPK kadar abunya 1,6\%. Tingginya kadar abu bahan berkorelasi dengan rendahnya kelarutan dan viskositas kitosan.

Hasil pengujian viskositas larutan kitosan $1 \%(\mathrm{~b} / \mathrm{v})$ dalam pelarut asam asetat $1 \%$ menunjukkan bahwa kitosan dari cangkang udang windu mempunyai viskositas sedang ( $>200 \mathrm{cP}$ ) yaitu antara 330,3-461,3 cP. Kitosan tipe technical grade (produk Sigma) mempunyai karakteristik viskositas yang sama.

Densitas curah kitosan asal kitin udang windu berkisar antara 0,166-0,178 $\mathrm{g} / \mathrm{mL}$, lebih rendah dari densitas curah kitosan komersial asal kepiting (crab kitosan) antara 0,18-0,33 g/mL. Kemampuan mengikat air (WBC) kitosan sekitar 504-529\% lebih rendah dari WBC yang dilaporkan untuk crab kitosan antara 581-1150\%.

Kemampuan mengikat lemak (FBC) rata-rata 416,5\% untuk minyak kedelai, 503\% untuk minyak jagung, dan 400,8\% untuk minyak wijen. Nilai FBC dari kitosan asal cangkang udang lebih tinggi dari FBC kitosan komersial asal cangkang kepiting (Sigma Co.).

\section{Daftar Pustaka}

Alimuniar, A.; Zainudin, R., An economical technique for producing chitosan. In Advances in Chitin and Chitosan; Brine, C. J.; Sanford, P. A.; Zikakis, J. P.; Eds., Elsevier Applied Science, 1992, Essex UK, 627-632.

Cho, Y. I.; No, H. K., Effective Deproteinization Under Autoclaving Conditions for Preparation of Chitin, Journal of Korean Society for Chitin and Chitosan, 1999, Vol. 4(3), 152-155.

Khan, T. A.; Peh, K. K.; Ch'ng, H. S., Reporting degree of deacetylation values of chitosan: the influence of analytical methods", Journal of Pharmacy and Pharmaceutical Science, 2002, Vol. 5(3), 205-212.

Morjani, M. N.; Achutta, V.; Khasim, D. I., Parameters affecting theviscosity of chitosan from prawn waste, Food Science and Technology, 1975, Vol. 12, 187-189.

No, H. K.; Meyers, S. P.; Lee, K. S., Isolation and Characterization of Chitin from Crawfish Shell Waste, Journal of Agricultural and Food Chemistry, 1989, Vol. 37(3), 575-579.

No, H. K.; Meyers, S. P., Preparation and Characterization of Chitin and Chitosan: A Review, Journal of Aquatic Food Product Technology, 1995, Vol. 4(2), 27-52.

No, H. K.; Cho, Y. I.; Meyers, S. P., Effective Deacetylation of Chitin under Conditions of $15 p s i / 121^{\circ} \mathrm{C}$, Journal of Agricultural and Food Chemistry, 2000a, Vol. 48(6), 2625-2627

No, H. K.; Lee, S. H.; Meyers, S. P., Correlation Between Physcochemical Characteristics and Binding Capacities of Chitosan Products, Journal of Food Science, 2000b, Vol. 65(7), 1134-1137.

No, H. K.; Lee, S. H.; Park, N. Y.; Meyers, S. P., Comparisation of Physcochemical, Binding, Antibacterial Properties of Chitosan Prepared 
without and with Deproteinization, Journal of Agricultural and Food Chemistry, 2003, Vol. 51(26), 7659-7663.

Prasetio, W. K., PengolahanLimbah Cangkang Udang, 2006, http://www. kompas.com/htm (akses 18 September 2006).

Rout, S. K., Physicochemical, functional, and spectroscopic analysis of crawfish chitin and chitosan as affected by process modification, Dissertation, Louisiana State University, USA, 2001.

Shahidi, F.; Arachchi, J. K. V.; Jeon, Y. J., Food Application of Chitin and Chitosan, Food
Science and Technology, 1999, Vol. 10(20), 37-51.

Shahidi, F.; Synowiecki J., Isolation and characterization of nutriens and value-added products from snow crab (Chinoecetesopilio) and shrimp (Pandalus borealis)processing discards, Journal of Agricultural and Food Chemistry, 1991, Vol.39(8), 1527-1532.

Tolaimate, A.; Desbrieres, J.; Rhazi, M; Alagui, A., On the influence of deacettylation process on physicochemical characteristics of chitosan from squin chitin, Polymer, 2000, Vol. 41(7), 2463-2469. 